\title{
Asymmetric Strecker-Type Reaction of Nitrones Using Cyanohydrin
}

\section{Category}

Metal-Mediated

Synthesis

\section{Key words}

magnesium

tartramide

Strecker reaction

nitrones

cyanohydrin<smiles>[R][N+](=C)[O-]</smiles><smiles>CN(O)C(C#N)c1ccccc1</smiles>

$80 \%$ yield $89 \%$ ee<smiles>N#CC(c1ccc2ccccc2c1)N(O)Cc1ccccc1</smiles>

$73 \%$ yield $96 \%$ ee
$47 \%$ yield $72 \%$ ee<smiles>CC(C#N)N(O)Cc1ccccc1</smiles>

94\% yield $97 \%$ ee<smiles>N#CC(c1ccccc1)N(O)Cc1ccccc1</smiles>

$58 \%$ yield $96 \%$ ee<smiles>N#CC(Cc1ccccc1)N(O)C1CCCCC1</smiles>

$97 \%$ yield<smiles>COc1ccc(C(C#N)N(O)Cc2ccccc2)cc1</smiles>

$72 \%$ yield $90 \%$ ee<smiles>CC(C)(C)C(C#N)N(O)Cc1ccccc1</smiles>

$88 \%$ yield $93 \%$ ee
Significance: An asymmetric Strecker-type reaction of various nitrones with acetone cyanohydrin using a magnesium- $(R, R)$-tartramide complex was developed to successfully prepare optically active (S)- $\alpha$-amino nitrile derivatives in excellent yield. Thereby, the acetone cyanohydrin serves as a less harmful and easy-to-handle synthetic equivalent of $\mathrm{HCN}$ and TMSCN.
Comment: The reaction mechanism is proposed to proceed as follows: first, the reaction of cyanohydrin and the $(R, R)$-tartramide with $\mathrm{MeMgBr}$ forms the corresponding bromomagnesium salts. The tartramide magnesium salt might be further deprotonated by DBU to form a magnesium atecomplex which coordinates the nitrone. Transfer of the cyano group from the cyanohydrin magnesium salt to the nitrone occurs from the re face, forming specifically the $(S)$-enantiomer. 